\title{
An approach to predict chemical composition of goat Longissimus thoracis et lumborum muscle by Near Infrared Reflectance spectroscopy
}

\author{
Alfredo Teixeira ${ }^{\mathrm{a}, \mathrm{b}, *}$, António Oliveira ${ }^{\mathrm{a}, \mathrm{b}}$, Katia Paulos $^{\mathrm{a}, \mathrm{b}}$, Ana Leite ${ }^{\mathrm{a}, \mathrm{b}}$, \\ Anabela Marcia ${ }^{a}$, André Amorim ${ }^{\mathrm{a}}$, Etelvina Pereira ${ }^{\mathrm{a}}$, Severiano Silva ${ }^{\mathrm{b}, \mathrm{d}}$, \\ Sandra Rodrigues ${ }^{\mathrm{a}, \mathrm{c}}$ \\ a School of Agriculture, Polytechnic Institute of Bragança, Campus Sta Apolónia Apt 1172, 5301-855 Bragança, Portugal \\ b CECAV, Animal and Veterinary Research Centre, Portugal \\ c CIMO, Mountain Research Centre, Portugal \\ d University of Trás-os-Montes and Alto Douro, Quinta de Prados, Apt 1013, 5001-801 Vila Real, Portugal
}

\section{A R T I C L E I N F O}

\section{Article history:}

Received 16 October 2014

Received in revised form 24 February 2015

Accepted 10 March 2015

Available online 18 March 2015

\section{Keywords:}

NIRS

Goat meat

Prediction

Chemical composition

\begin{abstract}
A B S T R A C T
The ability of near infrared reflectance spectroscopy (NIRS) to estimate the protein, moisture, connective tissue and ash content in the Longissimus thoracis et lumborum (LTL) muscle of goat was studied. Samples $(n=240)$ of the LTL muscle were taken from the 8th to 13 th rib cut of goat carcasses. Samples were scanned in a FT-NIR Master ${ }^{\mathrm{TM}}$ N500 (BÜCHI) over a NIR spectral range of $4000-10,000 \mathrm{~cm}^{-1}$ with a resolution of $4 \mathrm{~cm}^{-1}$. It was collected 3 spectra per sample and subsequently, chemical analyses were performed at the Carcass and Meat Quality Laboratory of ESA-IPB. Using NirCal 1.5 it was developed a PLS regression model assaying, first and second derivatives as math treatment and multiplicative scatter correction for minimizing scattering effect on the spectra database recorded $(n=240)$. The best calibrations' models show relatively good predictability for protein (standard error of prediction $\mathrm{SEP}=0.43$; coefficient of determination $R^{2}=0.91$ ), moisture ( $\mathrm{SEP}=0.48 ; R^{2}=0.92$ ). Calibrations' models obtained are important as a first attempt to predict the chemical composition of goat meat by NIRS. More experimental data are needed to improve the accuracy of these calibrations.
\end{abstract}

(c) 2015 Elsevier B.V. All rights reserved.

\section{Introduction}

The near-infrared spectroscopy (NIRS) using the Fourier transform (FT) is a technology known by the end of 1960s when a computerized spectrophotometer NIR was

\footnotetext{
* Corresponding author at: School of Agriculture, Polytechnic Institute of Bragança. Campus Sta Apolónia Apt 1172, 5301-855 Bragança, Portugal. Tel.: +3512733303206.

E-mail address: teixeira@ipb.pt (A. Teixeira).
}

developed, and its applicability to the analysis of meat was shown (Ben-Gera and Norris, 1968). NIRS technology is currently a highly versatile tool used in diverse fields including the food industry and particularly in animal science to predict the chemical and physical composition of meat of different species (Weeranantanaphan et al., 2011). Due to this high versatility, the technology is being used for large-scale meat quality evaluation to predict chemical composition (Prieto et al., 2009). Identification and authentication is other applications for which NIR spectroscopy is a valuable tool as to identify (beef, pork, lamb 
and chicken) and authenticate different homogenized meat muscle species (Damez and Clerjon, 2013). In goats, as far as we know, there are no studies about the reliability and accuracy of this technology to characterize the meat composition. This work was a first approach to study the ability of NIRS to estimate the protein, moisture, connective tissue, ash and fat content in the Longissimus thoracis et lumborum (LTL) muscle of goat meat.

\section{Materials and methods}

A total of 400 goats of Serrana breed, between 5 and 9 years old and with live weights between 35 and $40 \mathrm{~kg}$ were used in this study of BISOVICAP (Project QREN SI I\&DT Co-Promotion n 21511/201) project. Samples $(n=240)$ of LTL muscle were taken from the 8th to 13th rib of the goat carcasses randomly selected. Samples were minced in a power mill (BÜCHI B-400) specific for meat and meat products obtaining homogeneous samples. Then the samples were scanned in a FT-NIR Master ${ }^{\mathrm{TM}}$ N500 (BÜCHI) equipped with a $360^{\circ}$ rotation system using a petri dish and over a NIR spectral range of $4000-10,000 \mathrm{~cm}^{-1}$ with a resolution of $4 \mathrm{~cm}^{-1}$. Three spectra per sample were measured and the mean spectrum was used for the development of the calibration equations.

Chemical analyses were performed at the Carcass and Meat Quality Laboratory of ESA-IPB. The protein content (NP 1612:1979), moisture (NP 1614:2002), ash (NP 1615:2002), fat content (AOAC, 1997) and collagen (hydroxyproline) (NP 1987: 2002) of the samples were determined.

Using version 5.5 of NIRCal BÜCHI software, chemometric calculations were developed to obtain a robust calibration. For calibrations, sets of calibration (C-set) and validation (V-set) spectra were used and a partial least square regression (PLS) model was developed. Only samples with reference analysis were used for calibration covering all expected allowable variations of the quality of the product. The combinations were chosen randomly. When selecting the spectra in the calibration and validation set, all spectra of one sample were assigned either to the calibration or to the validation set. The two sets were completely independent from each other and spectra in the V-set were used like unknown samples and only the C-set was involved in the loading calculation. A Normalization by Closure, Normalization Between 0 and 1 and MSC Full were preformed as math pretreatments to reduce baseline variations caused by scattering and first derivative Savitzky-Golay 9 Points was also used to reduce baseline effects and to increase smaller absorption peaks particularly eliminating the linear ordinate offset in spectra with very sharp absorption bands with high noise spectra.
Models using principal components analysis (PCA) and PLS have also been used previously in several muscles of different species (Cozzolino and Murray, 2004).

\section{Results and discussion}

Specific calibration equations were developed for the protein, moisture, ash, connective tissue and fat. The number of samples, means, standard deviations and ranges of chemical parameters measured is shown in Table 1. All values are within the expected values for fresh goat meat.

The best calibration equations as well as pretreatments, calibration wavelength ranges and the statistics obtained for each calibration are presented in Table 2. The consistency parameter describes the relationship between the standard errors of calibration (SEC) and validation (SEV) sets respectively (Nircal 4.21 manual, 2002). Values between 70 and $110 \%$ are acceptable. The Q-Value is a specific index used to give the overall quality of a NIR calibration measure of the quality of and it ranges from 0 to 1. A $Q$-value higher than 0.50 is acceptable for quantitative analysis. However, $Q$-value over 0.70 is considered robust. The highest $Q$-value was used as criteria for selection of the best calibration model (Nircal, 2002). This measure is useful as a tool for the judgment when different calibrations were compared. For values higher than 0.6 the calibrations became acceptable.

With the exception of ash content, all calibrations' models show relatively good predictability, particularly protein (Fig. 1) and moisture (Fig. 2) show the best SEC, SEP as well as coefficients of determination $(R)$. In mutton Viljoen et al. (2007) to predict contents of protein and moisture but also in fat have been predicted this components with great accuracy.

The calibration models obtained show similar accuracy as the results reported by Sun et al. (2012) in a study about the potential of NIRS combined with chemometrics

Table 1

Statistical parameters (C-set/V-set).

\begin{tabular}{lllll}
\hline Parameters (\%) & $N$ & Mean & SD & Range (min/max) \\
\hline Protein & $165 / 66$ & $21.17 / 21.19$ & $1.11 / 1.11$ & $18.45-23.38 / 18.65-23.04$ \\
Moisture & $152 / 62$ & $76.25 / 76.27$ & $1.94 / 1.90$ & $70.25-80.12 / 71.52-80.02$ \\
Ash & $130 / 57$ & $2.44 / 2.45$ & $0.36 / 0.4$ & $1.32-3.07 / 1.38-3.05$ \\
Connective tissue & $84 / 42$ & $0.87 / 0.82$ & $0.36 / 0.32$ & $0.19-1.77 / 0.24-1.31$ \\
Fat & $50 / 16$ & $2.37 / 2.56$ & $1.01 / 0.92$ & $0.5-3.93 / 1.05-3.73$ \\
\hline
\end{tabular}

Table 2

Calibration and validation parameters to goat fresh meat.

\begin{tabular}{|c|c|c|c|c|c|}
\hline & Protein & Moisture & Ash & Connective Tissue & Fat \\
\hline Pretreatment & $\begin{array}{l}\text { Normalization } \\
\text { Between } 0 \text { and } 1\end{array}$ & MSC Full & $\begin{array}{l}\text { 1. Normalization } \\
\text { by Closure } \\
\text { 2. First Derivative } \\
\text { Savitzky-Golay } 9 \\
\text { Points }\end{array}$ & $\begin{array}{l}\text { 1. Normalization } \\
\text { Between } 0 \text { and } 1 \\
\text { 2. First Derivative } \\
\text { Savitzky-Golay } 9 \\
\text { Points }\end{array}$ & $\begin{array}{l}\text { 1. First Derivative } \\
\text { Savitzky-Golay } 9 \\
\text { Points } \\
\text { 2. MSC Full }\end{array}$ \\
\hline Wavelength $\left(\mathrm{cm}^{-1}\right)$ & $4200-10,000$ & $4200-10,000$ & $4200-10,000$ & $4200-10,000$ & $4200-10,000$ \\
\hline Method & PLS & PLS & PLS & PLS & PLS \\
\hline SEC & 0.33 & 0.54 & 0.08 & 0.19 & 0.41 \\
\hline SEP & 0.43 & 0.48 & 0.28 & 0.24 & 0.49 \\
\hline C-set R & 0.91 & 0.92 & 0.94 & 0.72 & 0.83 \\
\hline V-set R & 0.87 & 0.94 & 0.52 & 0.46 & 0.60 \\
\hline Consistency & 77.45 & 112.67 & 30.25 & 78.71 & 82.84 \\
\hline
\end{tabular}




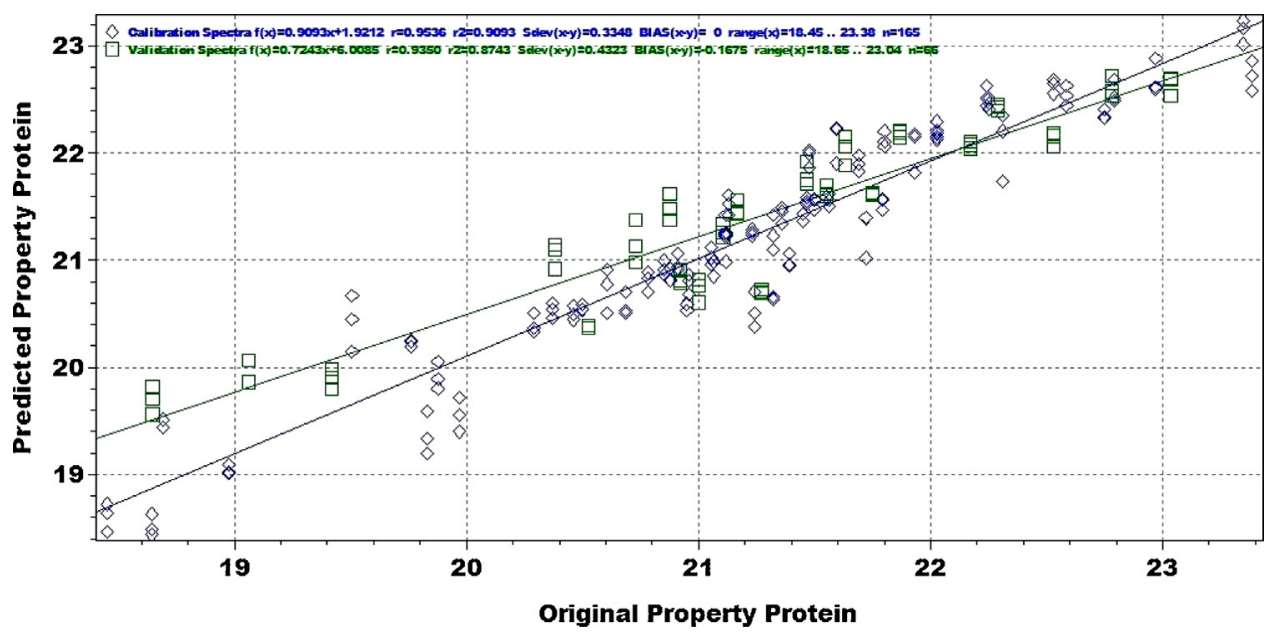

Fig. 1. Relationship between original and predicted properties for protein.

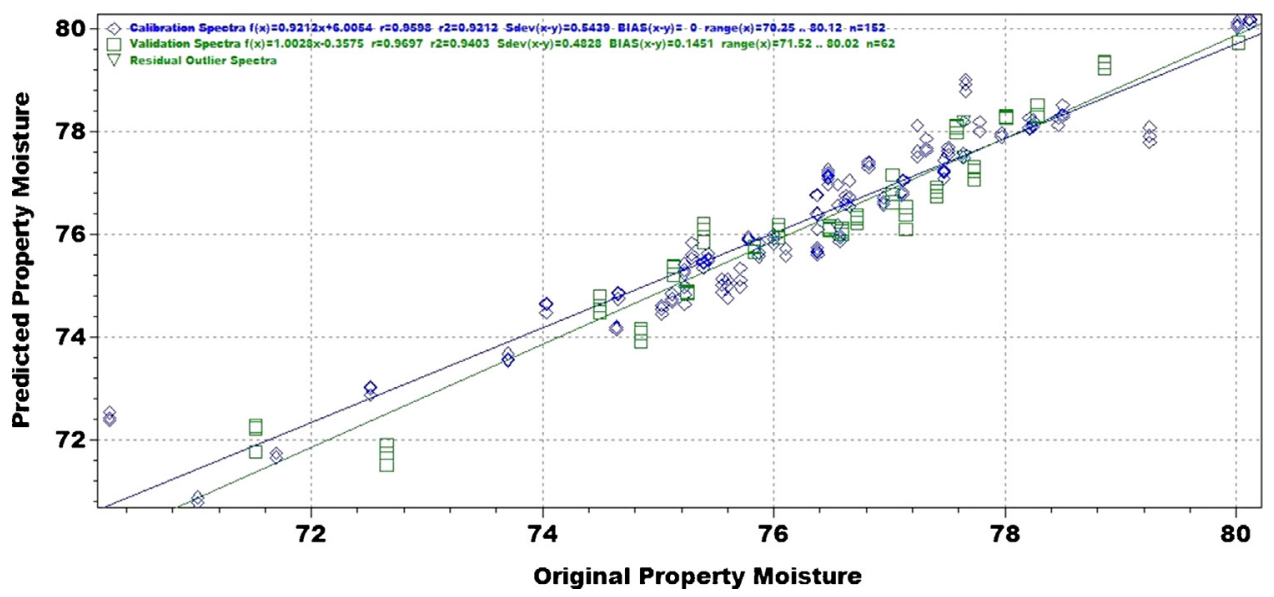

Fig. 2. Relationship between original and predicted properties for moisture.

to classify the geographical origins of lamb meats. Also good results were accounted by Guy et al. (2011) that use the NIRS to predict lamb meat fatty acid composition.

Calibrations from BÜCHI in Iberian pig meat for prediction chemical composition by Luna Delgado et al. (2004) have produced results with the same accuracy for protein and moisture as the calibrations obtained this study. However fat prediction was much better predicted than in goat meat.

\section{Conclusions}

The calibration models obtained are important as a first attempt to predict the chemical composition of goat meat by NIRS. The NIRS technology combined with chemometrics will be a useful tool to know raw goat meat composition and select material improving the quality of meat processing. More experimental are needed to improve the accuracy of these calibrations and particularly for fat and ash prediction equations an even distribution of reference values along the calibration range should be taken into account.

\section{Conflict of interest}

We wish to confirm that there are no known conflicts of interest associated with this publication and there has been no significant financial support for this work that could have influenced its outcome.

\section{Acknowledgement}

We gratefully acknowledge QREN-COMPETE, PO REGIONAL DO NORTE, for financial support of the Project BISOVICAP (Project QREN SI I\&DT Co-Promotion $\mathrm{n}^{\circ}$ $21511 / 201)$.

\section{References}

AOAC, 1997. International PVM 4. Determination of Total Fat in Foods and Feeds by the Caviezel Method, Based on a Gas Chromatographic Technique.

Ben-Gera, I., Norris, K.H., 1968. Direct spectrophotometric determination of fat and moisture in meat products. Journal of Food Science 33, 64-67. 
Cozzolino, D., Murray, I., 2004. Identification of animal meat muscles by visible and near infrared reflectance spectroscopy. LWT - Food Science and Technology 37, 447-452.

Damez, J.L., Clerjon, S., 2013. Quantifying and predicting meat and meat products quality attributes using electromagnetic waves: an overview. Meat Science 95, 879-896.

Guy, F., Prache, S., Thomas, A., Bauchart, D., Andueza, D., 2011. Prediction of lamb meat fatty acid composition using nearinfrared reflectance spectroscopy (NIRS). Food Chemistry 127, 12801286.

Luna Delgado, P., Ruz-Gómez, A., De Pedo, E., Garrido-Varo, A.,2004. Assessing the ability of a FT-NIR pre-calibrated instrument for prediction of chemical composition in Iberian pig meat. In: Near Infrared Spectroscopy: Proceedings of the 11th International Conference. NIR Publications, pp. 529-533.

Nircal 4.21 Manual, 2002, Büchi Labortechnik AG, CH-Flawil.

NP-1612, 1979. Carnes, derivados e produtos cárneos. Determinação do teor de azoto total. Método de referência. IPQ, Lisboa.
NP-1614, 2002a. Carnes, derivados e produtos cárneos. Determinação da humidade. Processo de referência. IPQ, Lisboa.

NP-1615, 2002b. Carnes, derivados e produtos cárneos. Determinação da cinza total. Processo de referência. IPQ, Lisboa.

NP-1987, 2002c. Carnes, derivados e produtos cárneos. Determinação de hidroxiprolina. Processo de referência. IPQ Lisboa.

Prieto, N., Roehe, R., Lavín, P., Batten, G., Andrés, S., 2009. Application of near infrared reflectance spectroscopy to predict meat and meat products quality: a review. Meat Science 83, 175-186.

Sun, S., Guo, B., Wei, Y., Fan, M., 2012. Classification of geographical origins and prediction of $\left(\delta^{13} \mathrm{C}\right.$ and $\left(\delta^{15} \mathrm{C} \mathrm{N}\right.$ values of lamb meat by near infrared reflectance spectroscopy. Food Chemistry 135, 508-514.

Viljoen, M., Hoffman, L.C., Brand, T.S., 2007. Prediction of the chemical composition of mutton with near infrared reflectance spectroscopy. Small Ruminant Research 69, 88-94.

Weeranantanaphan, J., Downey, G., Allen, P., Sun, D.W., 2011. A review of near infrared spectroscopy in muscle food analysis: 2005-2010. Journal of Near Infrared Spectroscopy 19, 61-104. 